6 ケ月間のサーキットジムの利用が中高齢女性の筋・脂肪横断面積と筋力に及ぼす影響

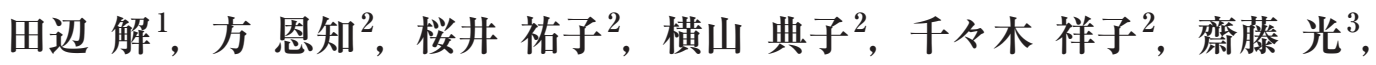
津田 曈美 $^{3}$, 齋藤 直美 ${ }^{4}$, 久野 譜也 $^{2}$

\title{
The effect of 6-month use of circuit gym on muscle and fat cross-sectional area and muscle strength in middle and older-aged women
}

\author{
Kai Tanabe $^{1}$, Eunji Bang ${ }^{2}$, Yuko Sakurai ${ }^{2}$, Noriko Yokoyama ${ }^{2}$, Shoko Chijiki ${ }^{2}$ Hikaru Saito $^{3}$, \\ Hitomi Tsuda $^{3}$, Naomi Saito ${ }^{4}$ and Shinya Kuno ${ }^{2}$ \\ ${ }^{1}$ 駒沢女子大学人間健康学部健康栄養学科, ₹ 206-8511 東京都稲城市坂浜 238 (Fuculty of Human Health Department of \\ Health and Nutrition Sciences, Komazawa Women's University, 238 Sakahama, Inagi, Tokyo 206-8511, Japan) \\ 2 筑波大学大学院人間総合科学研究科, ₹ 305-8577 茨城県つくば市天王台1-1-1 (Graduate School of Comprehensive Hu- \\ man Sciences, University of Tsukuba, 1-1-1 Tennodai, Tsukuba, Ibaraki 305-8577, Japan) \\ ${ }^{3}$ 株式会社カーブスジャパン，＝108-0023 東京都港区芝浦3-9-1 (Curves Japan Co., Ltd, 3-9-1 Shibaura, Minato, Tokyo \\ 108-0023, Japan) \\ ${ }^{4}$ 株式会社つくばウエルネスリサーチ，％211-8519 千葉県柏市若柴178-4 (Tsukuba Wellness Research Co., Ltd, 178-4 \\ Wakashiba, Kashiwa, Chiba 211-8519, Japan)
}

Received: March 15, 2018 / Accepted: June 20, 2018

\begin{abstract}
This study examined the effects of a 6-month circuit gym workout on muscle and fat cross-sectional area (CSA) and muscle strength in middle-aged and older women. The participants were 49 women without severe metabolic disease, exercise limitation, or exercise habits. They were randomly assigned to two groups, circuit gym using group (CRT: $n=25$ ) and walking group (WALK: $\mathrm{n}=24$ ). Both groups followed the exercise program for 6 months. Thigh and abdominal CSA before and after the program were measured using magnetic resonance imaging. Moreover, knee extensor/flexor and hip flexor strength were measured using a dynamometer. After completion of the exercise program, CSA of the psoas major muscle and isokinetic knee and hip flexion strength significantly increased in the CRT group compared with the WALK group (CSA: $7.1 \%$ vs $1.4 \%$ respectively; isokinetic strength: $7.5 \%$ vs $-4.3 \%$ (knee), $23.6 \%$ vs $2.2 \%$ (hip), respectively). In addition, subcutaneous adipose tissue of the thigh in the CRT group significantly decreased compared with that in the WALK group $(-6.5 \%$ vs $-1.8 \%$, respectively). These results imply that in middle-aged and older women, the use of circuit gym leads to a more effective increase in CSA of the psoas major muscle, decrease in thigh subcutaneous adipose tissue, and increase in knee and hip flexor strength compared with brisk walking.
\end{abstract}

Jpn J Phys Fitness Sports Med, 67(4): 281-290 (2018)

Keywords : circuit-based exercise, walking, randomized controlled trial

緒言

世界に先がけて超高齢社会をむかえる我が国では，い かに多くの国民が健康寿命を伸ばし，生活の質を高める かが重要課題として位置づけられている。運動を中心と した健康づくりは，生活習慣病予防や介護予防に効果が あり，健康寿命の延伸につながるとされるが，運動を習 慣化できている国民は多くないのが現状である1)。運動 の実行に障壁となる要因は，時間がない，激しい運動が 嫌い，または運動施設へのアクセスが不便などがあげら れ2), これらの障壁を越えやすいプログラム, サービス
あるいは環境づくりが求められている.

高齢者の生活習慣病予防や介護予防には, 有酸素性運 動だけでなく抵抗性運動（筋力や筋量の維持・増加を目 的に筋へ一定の負荷をかけて行う運動）やストレッチを 含めた複合的な運動を習慣的に行うことが20年前から推 奨されてきた ${ }^{3)}$. 中でも筋力・筋量の維持・増加を主な 目的として行う抵抗性運動トレーニングは，2 型糖尿病 等の代謝性疾患やサルコペニアにともなう運動器疾患り スクの減少に寄与することが明らかとなっている。しか しながら, 我が国で週 2 回以上の抵抗性運動トレーニン グを行っている者の割合は $3.9 \%$ と低く，習慣化しにく 
いことが課題とされている ${ }^{4}$

一方, 我が国では, サーキットジムの利用者がここ数 年間で急増している。 サーキットジムとは, サーキット トレーニングのサービスに特化したフィットネスクラブ のことであり ${ }^{5)}$, 主に抵抗性運動, 有酸素性運動及びス トレッチを組み合わせた複合的な運動プログラムと実践 指導のサービスを利用者に提供している，大規模施設の フィットネスクラブの新規出店数が伸び悩む（2005〜 2012年で平均 28 店/年) 中で, サーキットジムの新規出 店数は毎年一定数増加（平均 192 店/年）している ${ }^{5)}$. 本 研究で効果検証を行う女性専用サーキットジムは, 会員 も指導スタッフも女性限定とし，30分間で終了するとい う運動プログラムに加え，地域のスーパーマーケットの 一角で営業するなどアクセスのしやすさも手伝っで ${ }^{6}$, 営 業開始から 11 年間で 1,760 店埔となり, 会員数が 79 万人に 達した ${ }^{7)}$. 以上のことから, このようなサーキットジムは, より多くの国民が抵抗性運動を含む複合的な運動を習慣 化する形態の一つとして有用であると考えられる。

本研究で効果検証を行う女性専用サーキットジム利用 者の大半は, 60 歳以上の中高齢女性である7 ${ }^{7}$. 女性は男 性に比べて筋量が少なく, 体脂肪が多いこと采 及び運動 器の機能低下により要介護となる者の割合が男性よりも 高いこと ${ }^{9)}$ から, サーキットジムの継続的な利用が, 中 高齢女性のサルコペニア及び肥満の予防に効果があるか を検証することは有意義であると思われる。

ところで，このサーキットジムでは，油圧式マシンに よる抵抗性運動と有酸素性運動を交互に行うサーキット 式コンバインドトレーニングプログラム ${ }^{7.10)}$ を全会員に 提供している。 これに類似した運動トレーニングの健康 増進効果について高齢者を対象に検討した研究はいくつ かあり，これまでに持久的体力, 筋力及び筋パワーの増 加 ${ }^{11-13)}$, HDL コレステロールの増加や体脂肪の減少 ${ }^{11,13)}$, 認知機能の改善 ${ }^{14)}$, あるいは日常身体活動量の増加 ${ }^{10)}$ が 報告されている。このような研究の多くは実験室内で研 究者の監視の下で実行した運動プログラムの効果を検証 したものであるが，実生活の中で実存するサーキットジ ムを利用した場合には，必ずしも同様の効果が得られる とは限らない。なぜならば，実験室内で行う運動に比べ て実生活で行う運動は，その実行にあたり障壁が多くな るためである。このことは, 運動の実行頻度, アドヒア ランス，及び継続率の個人差を広げ，結果として運動プ ログラムの効果に違いをもたらす可能性がある。実環境 で実験室と同様の効果が得られた場合，その運動プログ ラムの公衆衛生的インパクトと普及可能性はより高まる ことから ${ }^{15)}$, 実存するサーキットジムの利用効果を検討 することは意義があると思われる。また，実際のサー キットジムの利用が筋量, 筋力及び体脂肪に及ぼす影響 を検討した研究は非常に少なく ${ }^{10)}$, 特にMRI (magnetic resonance imaging）で評価されるような筋・体脂肪横 断面積に与える影響を検討した研究は我々の知る限りみ られない. MRIは高い精度で筋や体脂肪の多少を身体部 位別に評価できる測定手法であり，目的とした部位に対 して選択的に筋肥大や脂肪減少が生じているかを確認で きる.したがって, MRIを用いて筋や体脂肪に対するサー キットジム利用効果を詳細に検証することは, 本研究の 仮説を明らかにする上で有用な情報を得られると考えら れる。

そこで，本研究では中高齢女性を対象にして，6か月 間のサーキットジムの利用が，筋・体脂肪横断面積及び 筋力に与える影響について明らかにすることを目的とし た。な扮, 本研究では, ウォーキングのみ行う群を比較 対照群とした。 ウォーキングは有酸素性運動の代表的な 運動で, 我が国の中高齢者において最も広く普及・定着 している運動様式である ${ }^{16)}$. ウォーキングで得られる健 康増進効果の大きさを基準として考え, サーキットジム で行う複合的な運動トレーニングの効果を検討すること で，その有用性を確認できると考えた。本研究では，中 高齢者に扒けるサーキットジムの利用は， ウォーキング に比べてより大きな筋横断面積と筋力の増加や体脂肪面 積の減少をもたらすと仮説を立て, この仮説を検証した。

\section{方法}

対象者 参加者の募集は，チラシの投函により行い，募 集チラシには, 研究期間中はサーキットジムの利用料が かからないこと及び研究への協力謝金を支払うことを記 した. 対象者の選定条件は, (1)60～85歳の女性，(2)心血 管系疾患やがんを患っていない者, (3)重度疾患がない者, (4)安静時血圧が収縮期血圧 $180 \mathrm{mmHg}$ 以上もしくは拡張 期血圧 $110 \mathrm{mmHg}$ 以上でない者, (5)医師に運動を制限さ れていないまたは禁止されていない者, (6)要介護 1〜 5 の認定を受けていない者，7慢性的な関節痛等で日常生 活に支障を来す痛みがない者及び8運動習慣がない者と した，応募した 147 名の内，上記の条件を満たす51名を 研究対象者とした。

対象者には，研究について紙面及び口頭により十分な 説明を行った，その後，同意書への署名による研究参加 の同意を得た。本研究は筑波大学大学院人間総合科学研 究科の研究倫理委員会の承認を受けた（課題番号第体 25-28号).

研究デザイン 対象者51名を事前評価時に調査・計測 した年齢，BMI，腹囲，血圧，筋力及び歩数をマッチン グした上で，無作為にサーキットジム利用群（CRT群； $\mathrm{n}=26$ ）とウォーキング群（WALK群；n=25）の 2 群に 分類した。介期間は，2013年 8 月〜 2014年 2 月の間の 6 ヶ月であり，評価はその前後 1 ヶ月以内の間に実施し 
た。なお，介入期間中に両群で 1 名ずつ辞退があったた め, 最終的な分析対象者はCRT 群25名とWALK 群24名 の計49名（70.6 \pm 7.4 歳, 60-85歳）とした。辞退者 2 名 の辞退の理由は, それぞれ体調不良と長期間の旅行であ り，すべて本研究の介入による影響とは関係のないもの であった。

\section{介入内容}

1.サーキットジム利用 (CRT) 群

CRT 群は, 通常営業する東京都内のサーキットジム （カーブス, カーブスジャパン, 東京） 3 店舗のうち自宅 に最も近い店舗に週 3 日の頻度で訪問し, 常駐するイン ストラクターの指導のもと, 通常サービスとして提供さ れるサーキット式コンバインドトレーニングプログラム を 6 ケ月間行った. トレーニング内容は, 12 種類の油圧 式マシンによる抵抗性運動（ショルダープレス, チェス トバック, バイセップトライセップ, ペックデック, レッ グエクステンション, レッグカール, スクワット, ヒップ アブダクター, アダクター, レッグプレス, グルート及び アブバック），ステップボード上で足踏みをする有酸素 性運動及びストレッチで構成された ${ }^{7,10)}$ 。運動プログラ ムの流れは, ウォーミングアップとしてストレッチ運動 を行った後, 抵抗性運動と有酸素性運動をそれぞれ 30 秒 交互に繰り返し，12種の抵抗性運動を全て行うルーティ ンを 2 セット行い, 最後にクールダウンとしてストレッ チ運動を行う形式であった。運動時間は, 全て合わせて 30 分間となるようにした。運動強度は，運動中の心拍 数が最大心拍数の $60-80 \%$ とすることを目標とした．イ ンストラクターは, 運動中に対象者自身で手指を使って 手首の脈を数えることにより心拍数を計測するよう指示 し, 目標心拍数の範囲内におさまるよう運動動作の強度 (マシンやステップの反復回数) を対象者に調整させた. また，上記運動以外の身体活動量や食事量は，介入期間 中に大きく変えないよう指示した.

\section{2. ウォーキング (WALK) 群}

WALK 群は, 加速度計内蔵歩数計 (HJ-730IT, オムロ ンヘルスケア社製, 京都) を腰部に装着し, 目標歩数を 1 週間で達成するウォーキングを 6 ケ月間行った。目標 歩数は, 歩数計でカウントされる $4 \mathrm{METs}$ 以上かつ10分 以上の連続歩行時の歩数 (しつかり歩数) が 1 週間の合 計で 9,000 歩 (3,000歩/日×3 日/週を目安）となるよう 設定した。なお，この目標歩数は，CRT群における 1 週間の運動量（サーキットジム30分/日×3 日/週）と おおよそ同程度になるように設定した。また，上記運動 以外の身体活動量や食事量は, 介入期間中に大きく変え ないよう指示した。ささらに, WALK群の対象者は, モチ ベーションの維持・向上のため, 月 1 回の頻度で指定施
設へ来場してもらい, 歩行量の確認と専門家による歩行 指導を実施した。

\section{測定項目}

1. 身体形態と血圧

身体形態は，身長，体重，BMI及び腹囲を測定した。 身長は, 身長計により $0.1 \mathrm{~cm}$ 単位で測定し, 体重は体重 体組成計 $(\mathrm{HBF}-354 \mathrm{IT}-2$, オムロンヘルスケア社製, 京 都）を用いて $0.1 \mathrm{~kg}$ 単位で測定した。測定された身長と 体重から BMI (body mass index $\left[\mathrm{kg} / \mathrm{m}^{2}\right]$ ) を算出した. 腹囲は，立位で軽く息を吐いた時にメジャーを用いて肋 骨最下縁と腸骨陵最上部の中間部位の周径囲を $0.1 \mathrm{~cm}$ 単 位で 3 回測定し, それらの平均值を腹囲として採用した。

血圧は, 自動電子血圧計（HEM-7250-IT, オムロンへ ルスケア社製, 京都) を用いて, 早朝安静空腹時に 3 回 計測した収縮期・拡張期血圧の各平均值を採用した。

\section{2. 大腿部および腹部横断面積}

MRIにより，大腿部と腹部の横断画像を 1 回撮影し, 骨格筋, 皮下脂肪, 内藏脂肪及び筋間 - 筋内脂肪の横断 面積（CSA： cross-sectional area）を計測した. MRIは, $0.25 \mathrm{~T}$ の永久磁石コイル型 MR装置 (AIRIS mate, 日立 メディコ社製，東京）を用いた，MRIの計測条件は先行 研究と同一にした ${ }^{17,18)}$. 大腿部は右脚の大転子と外側上 顆の $50 \%$ 部位の横断画像を, 腹部は腰椎 4 番と 5 番の 間の椎間板を中心とした横断画像をCSA解析に用いた. 大腿部と腹部のCSAの解析は, 画像処理ソフトウェア (SliceOmatic, Tomovision, Montreal, Canada)を用いて, 画像分析トレーニングを受けた 1 名の熟練者が 1 画像に つき 3 回行い, その平均值をCSAとして採用した ${ }^{17,18)}$. 本研究の対象者 49 名について CSA 解析を各 3 回行った 際の測定変動係数 (CV : coefficient of variation) の平均 值は大腿筋で $\pm 0.24 \%$, 大腿部皮下脂肪で $\pm 0.45 \%$, 筋間・ 筋内脂肪で $\pm 0.45 \%$, 腹部皮下脂肪で $\pm 0.40 \%$ ，そして内 臓脂肪で士0.57\%であった。

\section{3. 筋力}

ダイナモメーター (Biodex System 3 Pro, Biodex Medical Systems, Inc., New York, USA) により, 等速 性筋力と等尺性筋力を測定した。等速性筋力は, 膝関節 伸展 ·屈曲筋力 $\left(60^{\circ} /\right.$ 秒, $180^{\circ} /$ 秒 $)$ 及び股関節屈曲筋 力 $\left(60^{\circ} /\right.$ 秒) を計測した。 それぞれ最大努力による筋力 発揮を 3 回行い, 出力トルクの最高值を採用した。等尺 性筋力は, 膝関節伸展 ·屈曲筋力を各 1 回計測し， 5 秒 間の最大努力での筋力発揮時における出力トルクの最高 值を採用した。なお，等速性及び等尺性膝関節伸展・屈 曲筋力の計測は, ダイナモメーターの座席に膝関節 $90^{\circ}$ かつ股関節 $90^{\circ}$ で座った姿勢で行った。いずれも十分な 
ウォーミングアップと動作練習を行った上で, 本測定を 実施した。

\section{4. 身体活動量}

身体活動量は, 加速度計内蔵歩数計（HJ-730IT，才 ムロンヘルスケア社製，京都）を用いて評価した ${ }^{19,20)}$. CRT群とWALK群の両群に対して, 睡眠や入浴時など 装着ができない場合を除いた起床から就寝まで歩数計を 腰部に装着させ，日常の身体活動量を計測した。なお， 計測期間は, 介入前の 2 週間と介入期間の最後の 2 週間 とし，それぞれ介入前と介入後の日常身体活動量とした。 装着期間中は, 通常通りの生活を行うよう指示し, 身体 活動記録用紙に旅行や出張などの非日常的な活動（CRT 群はサーキットジムのプログラム以外の非日常的な活 動）を行った日付，時間及び活動内容を記入させた。身 体活動量の評価には, 歩数計を装着した 2 週間のうち, 非日常的な活動日を除外した 7 日分のデー夕を用いた。 身体活動量の評価指標は，1日当たりの歩数，1日当た りのしっかり歩数（4METs以上かつ10分以上の連続 歩行時の歩数）及び 1 週間の $3 \mathrm{METs}$ 以上の身体活動量 [METs・時]とした。なお，CRT群に対しては，サー キットジム利用時には歩数計を装着しないよう指示した ため，計測された身体活動量はサーキットジム利用時の 身体活動量を除外したものとみなした。

\section{CRT群の運動トレーニング参加・実行状況}

CRT群が提出したサーキットジム利用日の記録から， 運動トレーニングの参加率を算出した。 また, 運動強度 を把握するため, インストラクターが 12 種類の油圧式マ シンの反復回数と運動実施時に対象者自身で手指を使っ て手首の脈を数えて測った心拍数を月 1 回の頻度で計 測・記録した。

\section{6。基本属性，食習慣及び飲酒習慣の調査}

対象者の年齢, 食習慣及び飲酒習慣を自記式アンケー トにより調査した。食習慣は,「食事を摂る時間帯は決 まっているか」,「食事の量は腹八分目にしているか」, 「食 事のカロリーや量が多い場合, 残すことをしているか」, 「朝食は摂っているか」，「普段間食（夜食を含む）をする ことがあるか」，「普段外食をすることがあるか」，「外食 するときや食品を購入するときにカロリー表示や栄養成 分表示を参考にしているか」及び「脂分の多い食べ物を 食べるか」の 8 項目について 4 件法で回答を得た ${ }^{20)}$. こ れらの回答について, 最も好ましい回答肢を 1 点, 最も 好ましくない回答肢を 4 点とし数值化した. 飲酒習慣は, 「扮酒を飲む頻度」を「ほとんど飲まない（1点）」〜「毎 日飲む（6 点)」の 6 件法で回答を得た ${ }^{20)}$.
統計解析 基本統計量は, 平均值および標準偏差とした。 CRT 群とWALK 群の 2 群間の対比較には対応のない $\mathrm{t}$ 検定を用いた．介入前後に扔ける各変数の変動が 2 群間 で異なるかを検討するため, 二元配置反復測定分散分析 （Two-way Repeated Measures ANOVA）を実施した. この分析で群 $\times$ 時間の交互作用に有意性が認められた場 合には, Bonferroni法により単純主効果の検定を行った。 ただし，食習慣スコアと飲酒習慣スコアについては，介 入前後の比較にWilcoxonの符号付き順位検定を用いた。 有意水準は $5 \%$ とし, 統計処理には統計解析ソフトウェ ア（IBM SPSS Statistics 20，日本IBM社製，東京）を用 いた。

\section{結 果}

対象者の特徴とCRT 群におけるトレーニングの参加・ 実行状況 全体及び群別にみた対象者の特徽をTable 1 に示した，両群の年齢，身長，体重，BMI，腹囲及び血 圧に有意差はなかった。

CRT 群のトレーニング参加率は，25名中 23 名が $100 \%$ （72日）の参加率であった。なお，100\%に至らなかった 2 名の対象者の参加率は，99\%（71日）と94\%（68日） であった。

CRT群における 12 種目の油圧式マシンの反復回数は, 全種目で 1 ケ月毎に漸増し，介入開始月に比べて介入最 終月に 25-53\%増加した。 また，介入期間中における運 動実施時の心拍数は，104-116拍/分（最大心拍数の 7078\%）の範囲であり，目標（最大心拍数の 60-80\%）の範 囲内であった。

筋横断面積の变化 Table 2 に介入前後の体重，BMI及 び筋横断面積を示した。体重とBMIについてはそれぞれ 交互作用に有意性はなく, 時間のみ有意な主効果がみら れ，いずれも約 $1 \%$ とわずかであるが，介入前に比べて 介入後で有意に減少した。大腿筋 CSAについては有意 な交互作用が認められず，時間と群の両要因ともに有意 性はなかった。この結果は, 大腿伸筋群と屈筋群に分け た場合にも同様であった。一方，大腰筋 CSAについては 有意な交互作用がみられ，時間に関する単純主効果の検 定により CRT 群では介入前の值に比べて介入後で有意 な増加が認められ $(+7.1 \% ; \mathrm{p}<0.05)$, WALK群では介 入前後の值に有意な増加が認められなかった $(+1.4 \%$; $\mathrm{p}=0.39)$.

体脂肪横断面積の变化 Table 3 に介入前後の体脂肪 CSA を示した，大腿部の筋間・筋内脂肪，腹部の皮下脂 肪及び内臓脂肪のCSAについては交互作用に有意性は なく, 時間の主効果のみ有意性が認められ，いずれの恋 数も介入前に比べて介入後で有意に減少した。一方，大 
Table 1. Characteristics of subjects at baseline

\begin{tabular}{lcccc}
\hline \multicolumn{1}{c}{ Characteristics } & All subjects $(\mathrm{n}=49)$ & CRT group $(\mathrm{n}=25)$ & WALK group (n=24) & P value (t-test) \\
\hline Age (years) & $70.6 \pm 7.4$ & $70.7 \pm 7.5$ & $70.4 \pm 7.4$ & 0.902 \\
Height $(\mathrm{cm})$ & $152.5 \pm 5.4$ & $153.4 \pm 5.3$ & $151.5 \pm 5.4$ & 0.229 \\
Weight $(\mathrm{kg})$ & $57.0 \pm 9.0$ & $57.9 \pm 8.6$ & $56.0 \pm 9.4$ & 0.467 \\
BMI (kg/m $)$ & $24.5 \pm 3.5$ & $24.6 \pm 3.6$ & $24.3 \pm 3.5$ & 0.761 \\
Waist circumference $(\mathrm{cm})$ & $91.0 \pm 9.1$ & $91.5 \pm 8.9$ & $90.4 \pm 9.5$ & 0.656 \\
SBP (mmHg) & $134.6 \pm 17.0$ & $135.4 \pm 16.4$ & $133.8 \pm 17.9$ & 0.734 \\
DBP (mmHg) & $82.5 \pm 10.9$ & $83.1 \pm 12.4$ & $82.0 \pm 9.4$ & 0.740 \\
\hline
\end{tabular}

Values are means \pm SD, CRT: circuit gym using group, WALK: walking group, BMI: body mass index, SBP: systolic blood pressure, DBP: diastolic blood pressure.

腿部の皮下脂肪 CSA については有意な交互作用が認め られ, 単純主効果の検定では CRT 群のみ介入前に比べ て介入後で有意に減少した $(-6.5 \% ; p<0.05$ vs WALK 群 $-1.8 \%$; $\mathrm{p}=0.26$.

筋力の変化 Table 4には, 介入前後の筋力を示した 等速性膝関節伸展筋力 $\left(60,180^{\circ}\right.$ /秒 $)$ 及び等尺性膝関節 伸展・屈曲筋力については, いずれも交互作用に有意性 はなかったが，時間の主効果にのみ有意性が認められ， 介入前に比べて介入後で有意に増加した。等速性膝関節 屈曲筋力 $\left(180^{\circ} /\right.$ 秒 $)$ については有意な交互作用は認め られず，時間と群の主効果にも有意性はなかった。一 方，等速性膝関節屈曲筋力 $\left(60^{\circ} /\right.$ 秒 $)$ と等速性股関節 屈曲筋力 $\left(60^{\circ} /\right.$ 秒 $)$ については，有意な交互作用が認 められた。これらの変数について時間に関する単純主 効果の検定を行ったところ, 等速性膝関節屈曲筋力は CRT 群のみ介入前に比べて介入後で増加する傾向がみ られ $(+7.5 \% ; \mathrm{p}=0.05$ vs WALK群 $-4.3 \% ; \mathrm{p}=0.25)$, 等速性股関節屈曲筋力は CRT 群のみ介入前に比べて介 入後で有意に増加した $(+23.6 \% ; \mathrm{p}<0.05$ vs WALK群 $+2.2 \% ; \mathrm{p}=0.62$ ).

身体活動量の変化とWALK群の運動実行状況 Table 5 には，介入前後の身体活動量を示した，歩数については 交互作用に有意性が認められず，時間の主効果のみ有 意性がみられた，一方，しっかり歩数及び身体活動量 については有意な交互作用が認められ，いずれの変数 もWALK群のみ介入前に比べて介入後に有意に増加し た（それぞれ+1,290歩/日； $<<0.05,+8.8 \mathrm{METs}$ ・時/週； $\mathrm{p}<0.05)$.

食習慣と飲酒習慣の变化 食習慣と飲酒習慣に関する設 問のスコアについては, 両群ともに全ての項目で介入前
後に有意な差はなかった。 なお，介入前後における各ス コアの中央值の変化は次の通りである。「食事を摂る時 間帯は決まっているか」: CRT 群 $2.0 \rightarrow 1.0$ 点, WALK群 $2.0 \rightarrow 1.5$ 点,「食事の量は腹八分目にしているか」: CRT 群 $2.0 \rightarrow 2.0$ 点, WALK群 $2.0 \rightarrow 2.0$ 点, 「食事のカロリーや 量が多い場合, 残すことをしているか」: CRT 群 $2.0 \rightarrow 2.0$ 点, WALK群 $2.0 \rightarrow 2.0$ 点, 「朝食は摂っているか」: CRT 群 $1.0 \rightarrow 1.0$ 点, WALK群 $1.0 \rightarrow 1.0$ 点, 「普段間食（夜 食を含む）をすることがあるか」：CRT 群 $3.0 \rightarrow 3.0$ 点, WALK群 $2.0 \rightarrow 2.0$ 点, 「普段外食をすることがあるか」: CRT 群 $1.0 \rightarrow 1.0$ 点, WALK群 $1.0 \rightarrow 1.0$ 点, 「外食すると きや食品を購入するときにカロリー表示や栄養成分表 示を参考にしているか」:CRT 群 $2.0 \rightarrow 2.0$ 点, WALK 群 $3.0 \rightarrow 2.0$ 点及び「脂分の多い食べ物を食べるか」: CRT 群 $3.0 \rightarrow 3.0$ 点, WALK 群 $3.0 \rightarrow 3.0$ 点, 「㧍酒を飲む頻度」: CRT 群 $2.0 \rightarrow 1.0$ 点, WALK 群 $1.0 \rightarrow 1.0$ 点.

\section{考察}

本研究は, 中高齢女性に押ける 6 か月間のサーキット ジムの利用が, 筋・脂肪横断面積及び筋力に及ぼす影響 について明らかにすることを目的とした。 その結果, 中 高齢女性に抢ける6 朋間のサーキットジムの利用は, ウォーキングと比較してより大きな大腰筋横断面積の増 加, 等速性膝関節 ・ 股関節屈曲筋力の増加及び大腿部皮 下脂肪の減少をもたらすことが示唆された。

近年, サーキットジムの店舗数と利用者数が大幅に増 えているが5-7), 継続的な利用が筋横断面積に及ぼす効 果は明らかになっていない. 本研究では, 6 ケ月間のサー キットジム利用後に中高齢女性の大腰筋 CSA が $7.1 \%$ 増 加した。自体重とゴムチューブ負荷による抵抗性運動卜 レーニングを 6 ケ月間にわたり 70 歳代の高齢者に行わせ た先行研究では, 大腰筋CSAが10.9\%有意に増加したこ とを報告している ${ }^{21)}$. 本研究では, 先行研究ほどではな 

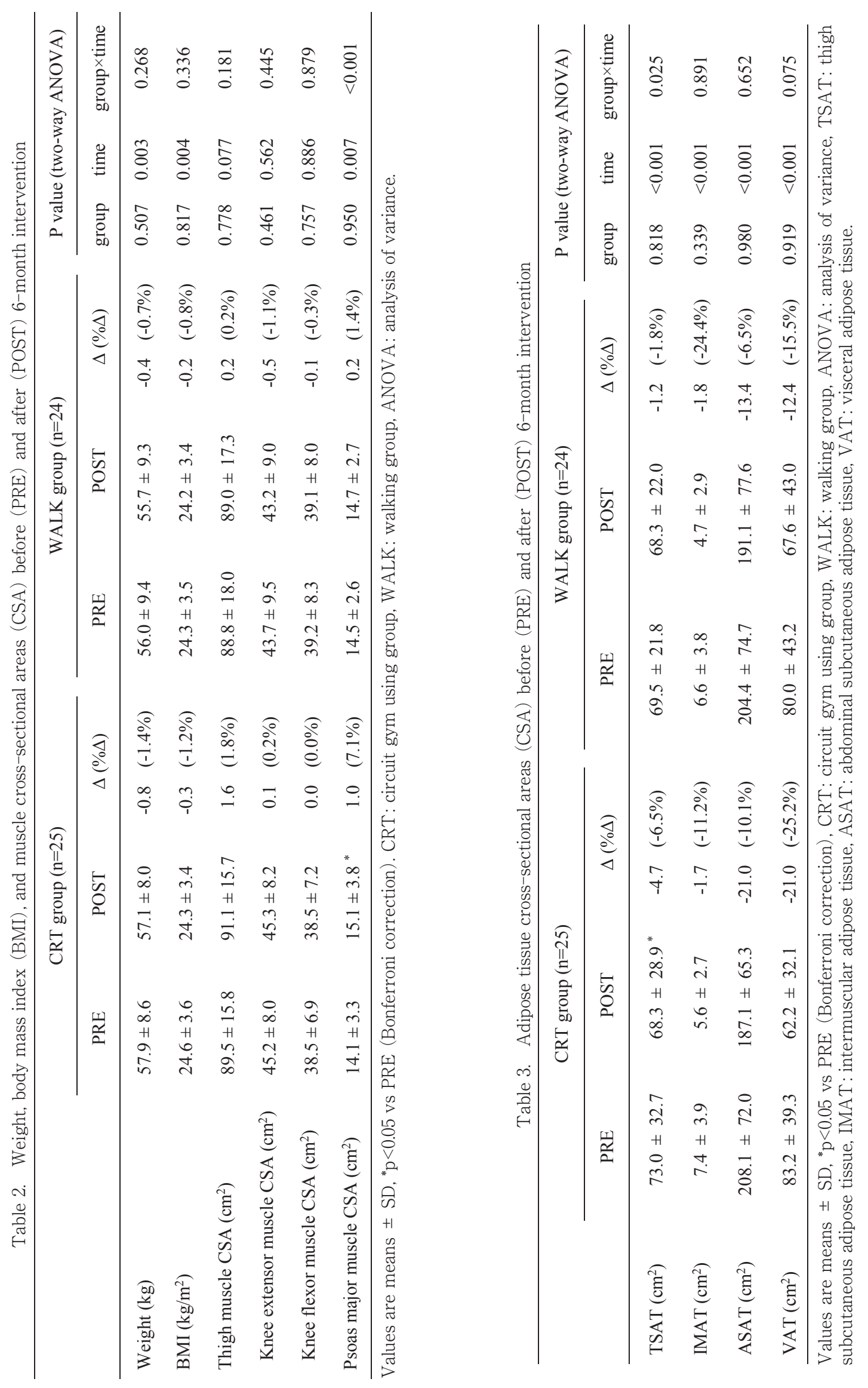

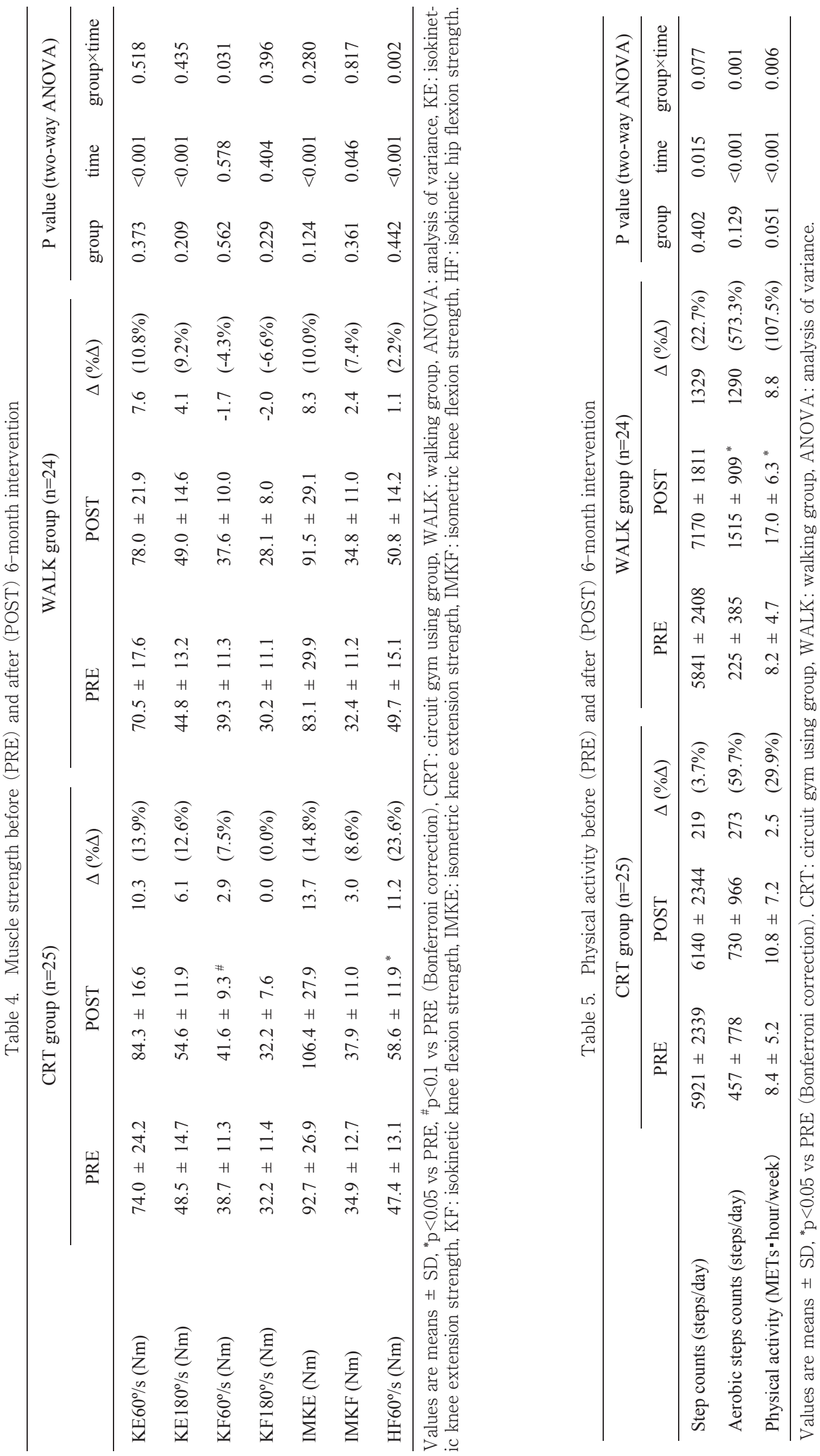
いがそれに近い大腰筋 CSA 増加効果が得られた. 先行研 究の増加率に至らなかったのは, 抵抗性運動の種類, 強 度,または実行頻度の違いが影響していると考えられる。 高齢女性に扔ける大腰筋 CSA は年間約 $0.8 \%$ の割合で減 少すること ${ }^{21)}$ や高齢者の大腰筋 CSA の増減は歩行能力 の高低と関係すること ${ }^{22)}$ を考え合わせると, 本研究でみ られた大腰筋 CSA の 7.1\%の増加は実質的にも有意義で あると考えられ，サルコペニア予防や介護予防にも一部 寄与すると推察される。

Davisら（2011）は，平均年齢15.8歳の過体重/肥満者 を対象にサーキット式コンバインドトレーニングを 16 週間行わせたところ, DXA（Dual X-ray Absorptiometry）で計測した全身除脂肪軟組織量は介入前後で有意 に変化しなかったとしている23)，サーキット式でない中 〜高強度のコンバインドトレーニングを中年女性に 21 週 間行わせた研究では, DXA で計測した腕の除脂肪軟組 織量は介入後に増加し, 有酸素性運動トレーニングのみ 実施した群と比較してもより大きな除脂肪軟組織量増加 を認めている ${ }^{24)}$ 。ただし, この先行研究では, 全身と下 肢の除脂肪軟組織量増加に関して, 有酸素性運動トレー ニングを上回る効果を認めていない ${ }^{24)}$ ，本研究で大腿 部CSAに有意な変化を認めなかったように, コンバイ ンドトレーニングが筋量に及ぼす効果はその内容, 強度, または部位によって大きく異なる可能性がある。，その詳 細を明らかにするためには, 今後より多くの研究が必要 となる。

これまでサーキットジムの利用が体脂肪に及ぼす影響 を検討した研究はないが, 本研究と類似した運動プログ ラムの継続的な実行は体脂肪の減少をもたらす可能性が 示されている ${ }^{11)}$ 。一方，中年者を対象としたサーキット 形式でないコンバインドトレーニングを行った研究で は, DXAで評価した全身体脂肪量が介入後に $4.8 \%$ 有意 に減少したものの, 有酸素性運動トレーニング単独群 $(-5.9 \%)$, 筋力トレーニング単独群 $(-2.2 \%)$ 及び対照群 $(-1.0 \%)$ との比較で群 $\times$ 時間の交互作用を認めていな $い^{24)}$. 本研究では, どちらの群も, 大腿部筋間・筋内脂 肪, 腹部皮下脂肪及び腹部内臟脂肪が介入後に有意に減 少した，また，大腿部皮下脂肪CSAは，WALK群 (-1.8\%) に比してサーキットジム利用後に有意に減少 $(-6.5 \%)$ する効果が認められた。 これらのことから, サーキット ジムの利用は体脂肪の減少をもたらすこと, 中でも大腿 部皮下脂肪に対してウォーキングを上回る減少効果があ ることが示唆された。しかし, CRT 群の大腿部皮下脂肪 CSAがWALK群よりも減少した理由は不明であり,こ の点については, 今後さらなる検討が必要である。

本研究は, サーキットジム利用が筋間・筋内脂肪に及 ぼす影響を初めて検討した，筋間・筋内脂肪の蓄積は, 身体不活動 ${ }^{25)}$, 糖尿病 ${ }^{26,27)}$, 脳卒中 ${ }^{28)}$ 及びメタボリック
シンドローム ${ }^{17,29)}$ と関連する可能性が報告されている. また, 筋間・筋内脂肪は, 有酸素性運動や抵抗性運動卜レー ニングによって減少することも報告されている ${ }^{30-32)}$ 。一 方で, 抵抗性運動卜レーニングにより高齢女性の下肢筋 間・筋内脂肪は減少したものの, 有酸素性運動トレーニ ングでは減少しなかったという報告もある ${ }^{32}$. 本研究で はCRT と WALKの両群で筋間・筋内脂肪の有意な減少 が認められた。これらのことから，本研究で行ったサー キット式コンバインドトレーニングとウォーキングは中 高齢女性の筋間・筋内脂肪を減少させる効果があること が示唆された。他部位の脂肪と比べて, 筋間・筋内脂肪 に対する運動トレーニングの効果を検討した研究は少な い. したがって, 運動トレーニングの種類, 期間, 強度, 及び頻度などによって筋間・筋内脂肪に対する影響が異 なるかを検討する余地がある。

本研究に打ける6 ケ月間のサーキットジム利用では, 等速性膝関節屈曲筋力が $7.5 \%$ 増加する傾向がみられ, 等速性股関節屈曲筋力は $23.6 \%$ 有意に増加した。 先行研 究では, 本研究に類似したサーキット式コンバインドト レーニングを 3 ケ月行った結果, 高齢者の膝関節伸展筋 力が $9.3 \%$ そして膝関節屈曲筋力が $14.4 \%$ 有意に増加した ことを報告している ${ }^{11)}$. 本研究はウォーキングを比較対 照としたため, ウォーキングでは強化されにくい部位の 筋肉に関して統計的に有意な効果が認められた可能性が ある、本研究に扔けるサーキットジムの運動プログラム には, 股関節周辺と体幹の筋群を強化する抵抗性運動が 7 種目含まれ，さらに有酸素性運動として大腿を腰の位 置まで引き上げるステップ運動が含まれていた，大腰筋 CSA の増加が認められたことからも, サーキットジムの 利用は特に股関節周辺筋群の増強に有効となる可能性が 示された。一方, サーキットジムの運動プログラムには 膝関節伸展筋群を強化する抵抗性運動が4種目あったも のの, 膝関節伸展筋力はウォーキングを上回る増強効果 がみられなかった. 大腿伸筋 CSA に有意な変化がなかっ たことも考え合わせると, 股関節周辺筋群に比べて膝関 節伸展筋群に対する負荷が十分でなかったことが考えら れる。.上り大きな膝関節伸展筋群の増強を期待するため には，この筋群を強化する油圧式マシンの反復回数を増 やす，反復速度を速めるなど運動負荷を増加する対策が 必要となる。

本研究はいくつかの限界がある，まず，本研究の対象 者は，60-85歳の中高齢女性を対象としているため，本 研究で得られた結果が, 男性や60歳未満や86歳以上の 女性に適用されるとは限らない。 また，本研究の介入期 間は 6 ヶ月間であり，それ以上の期間の介入効果，さら には将来的なサルコペニアの発生や要介護状態の発生を 抑制あるいは遅延できるか否かは検証できていない，最 後に, 本研究では比較対照をウォーキング群としたが, 
運動を実施しない群を設定していない，そのため，本研 究で認められたサーキットジム利用効果の解釈には制限 がある.これらの点については今後の検討が必要である.

\section{結 論}

中高齢女性における 6 ケ月間のサーキットジムの利用 は, ウォーキングと比較してより大きな大腰笳横断面積 の増加, 等速性膝関節屈曲・股関節屈曲筋力の増加及び 大腿部皮下脂肪の減少をもたらす効果があることが示唆 された

\section{利益相反}

本研究は, 株式会社カーブスジャパンより研究費の助成 を受け実施された (平成 25 年度受託研究：カーブス運動プ ログラムが高齢女性の筋量, 筋力, 及び歩行能力に及ぼす影 響に関する研究). 本研究には, 株式会社カーブスジャパン 社員の齋藤光と津田瞳美が共著者となっており, 彼らは対 象者の募集，サーキットジム利用時に取得するデータの管 理, 及び介入前後における測定場所への対象者の送迎を担 当した。

\section{謝 辞}

本研究は, 株式会社カーブスジャパンとの共同研究によ り行ったものである。本研究にご協力いただいた対象者及 び株式会社カーブスジャパンのスタッフの皆様に感謝申し 上げます。

\section{文献}

1）厚生労働省. 健康日本 21 最終評価, 51-55, 2011. http:// www.mhlw.go.jp/stf/houdou/2r9852000001r5gcatt/2r9852000001r5np.pdf.

2) Dishman RK, Sallis JF, Orenstein DR. The determinants of physical activity and exercise. Public Health Rep 100: 158-171, 1985.

3) American College of Sports Medicine Position Stand. Exercise and physical activity for older adults. Med Sci Sports Exerc 30: 992-1008, 1998. doi: 10.1097/00005768-199806000-00033.

4) 原田和弘, 柴田 愛, 李 恩兒, 岡 浩一朗, 中村好男：日本 人高齢者に拈ける筋力トレーニングの健康効果と阻害 要因の認知と筋力トレーニング行動の変容ステージと の関連 - Journal of Physical Activity and Healthに掲 載された英語論文の日本語による二次出版, 運動疫学研 究, 19: 62-74, 2017.

5）藤田美幸：産業構造分析における勝敗マトリクスの有 用性についてーフィットネスクラブ産業への適用 - , 現 代社会文化研究, 60: 67-84, 2015.

6）加藤清孝：女性専用フィットネスクラブ選択へ影響を 及ぼす要因の質的研究, スポーツマネジメント研究, 1 : 5-18, 2009. doi: 10.5225/jjsm.1.5.

7）株式会社カーブスジャパン：http://www.curves.co.jp/ (2018年 2 月 19 日アクセス可能)

8) Janssen I, Heymsfield SB, Wang Z, Ross R. Skeletal muscle mass and distribution in 468 men and women aged 18-88 yr. J Appl Physiol 89: 81-88, 2000. doi: 10.1152/jappl.2000.89.1.81.

9）内閣府. 平成 27 年版高齢社会白書, 2016. http:// www8.cao.go.jp/kourei/whitepaper/w-2015/zenbun/ pdf/1s2s_3_2.pdf.

10）大㴊修一, 河合 恒, 光武誠吾, 安齋紗保理, 猪股寛裕, 齋 藤 光, 津田瞳美, 中島友晴：高齢者に対するサーキット 式コンバインドトレーニングの日常活動量への効果, 体 力科学, 64: 305-314, 2015. doi: 10.7600/jspfsm.64.305.

11) Takeshima N, Rogers ME, Islam MM, Yamauchi $T$, Watanabe E, Okada A. Effect of concurrent aerobic and resistance circuit exercise training on fitness in older adults. Eur J Appl Physiol 93: 173-182, 2004. doi: 10.1007/s00421-004-1193-3.

12) 山内知子, 山田忠樹, MOHAMMOD MONIRUL ISLAM, 岡田暁宜, 高橋龍尚, 竹島伸生 : 高齢有疾患者の 総合的体力に対する well-rounded exercise program の有効性, 体力科学, 52: 513-523, 2003. doi: 10.7600/ jspfsm1949.52.513.

13) Lee S, Islam MM, Rogers ME, Kusunoki M, Okada A, Takeshima N. Effects of hydraulic-resistance exercise on strength and power in untrained healthy older adults. J Strength Cond Res 25: 1089-1097, 2011. doi: 10.1519/JSC.0b013e3181c69ea1.

14) Nouchi R, Taki Y, Takeuchi H, Sekiguchi A, Hashizume H, Nozawa T, Nouchi H, Kawashima R. Four weeks of combination exercise training improved executive functions, episodic memory, and processing speed in healthy elderly people: evidence from a randomized controlled trial. Age (Dordr) 36: 787-799, 2014. doi: 10.1007/s11357-013-9588-x.

15) Glasgow RE, Vogt TM, Boles SM. Evaluating the public health impact of health promotion interventions: The RE-AIM framework. Am J Public Health 89: 1322-1327, 1999. doi: 10.2105/AJPH.89.9.1322.

16）笹川スポーツ財団. スポーツライフ・データ 2016 , ス ポーツライフに関する調査報告書, 2016.

17) Bang E, Tanabe K, Yokoyama N, Chijiki S, Kuno S. Relationship between thigh intermuscular adipose tissue accumulation and number of metabolic syndrome risk factors in middle-aged and older Japanese adults. Exp Gerontol 79: 26-30, 2016. doi: 10.1016/ j.exger.2016.03.010.

18) Bang E, Tanabe K, Yokoyama N, Chijiki S, Tsuruzono T, Kuno S. Effects of daily walking on intermuscular adipose tissue accumulation with age: a 5-year followup of participants in a lifestyle-based daily walking program. Eur J Appl physiol 118: 785-793, 2018. doi: 10.1007/s00421-018-3812-4.

19) Kim J, Tanabe K, Yokoyama N, Zempo H, Kuno S. Association between physical activity and metabolic syndrome in middle-aged Japanese: a crosssectional study. BMC Public Health 11: 624, 2011. doi: 10.1186/1471-2458-11-624.

20) Kim J, Tanabe K, Yoshizawa Y, Yokoyama N, Suga Y, Kuno S. Lifestyle-based physical activity intervention 
for one year improves metabolic syndrome in overweight male employees. Tohoku J Exp Med 229: 1117, 2013. doi: 10.1620/tjem.229.11.

21）高橋康輝, 久野譜也：筋の萎縮とトレーニング 高齢期 における筋萎縮とトレーニング, 体育の科学, 55：608613, 2005 .

22）金 俊東, 久野譜也, 相馬りか, 増田和実, 足立和隆, 西嶋 尚彦, 石津政雄, 岡田守彦 : 加齢による下肢筋量の低下 が歩行能力に及ぼす影響, 体力科学, 49: 589-596, 2000. doi: 10.7600/jspfsm1949.49.589.

23) Davis JN, Gyllenhammer LE, Vanni AA, Meija M, Tung A, Schroeder ET, Spruijt-Metz D, Goran MI. Startup circuit training program reduces metabolic risk in Latino adolescents. Med Sci Sports Exerc 43: 2195-2203, 2011. doi: 10.1249/MSS.0b013e31821f5d4e.

24) Sillanpää E, Laaksonen DE, Häkkinen A, Karavirta L, Jensen B, Kraemer WJ, Nyman K, Häkkinen K. Body composition, fitness, and metabolic health during strength and endurance training and their combination in middle-aged and older women. Eur J Appl Physiol 106: 285-296, 2009. doi: 10.1007/s00421-009-1013-x.

25) Manini TM, Clark BC, Nalls MA, Goodpaster BH, Ploutz-snyder LL, Harris TB. Reduced physical activity increases intermuscular adipose tissue in healthy young adults. Am J Clin Nutr 85: 377-384, 2007. doi: 10.1093/ajcn/85.2.377.

26) Goodpaster BH, Thaete FL, Kelley DE. Thigh adipose tissue distribution is associated with insulin resistance in obesity and in type 2 diabetes mellitus. Am J Clin Nutr 71: 885-892, 2000. doi: 10.1093/ajcn/71.4.885.

27) Gallagher D, Kelley DE, Yim JE, Spence N, Albu
J, Boxt L, Pi-Sunyer FX, Heshka S; MRI Ancillary Study Group of the Look AHEAD Research Group. Adipose tissue distribution is different in type 2 diabetes. Am J Clin Nutr 89: 807-814, 2009. doi: 10.3945/ ajcn.2008.26955.

28) Ryan AS, Dobrovolny CL, Smith GV, Silver KH, Macko RF. Hemiparetic muscle atrophy and increased intramuscular fat in stroke patients. Arch Phys Med Rehabil 83: 1703-1707, 2002. doi: 10.1053/apmr.2002.36399.

29) Therkelsen KE, Pedley A, Speliotes EK, Massaro JM, Murabito J, Hoffmann U, Fox CS. Intramuscular fat and associations with metabolic risk factors in the framingham heart study. Arterioscler Thromb Vasc Biol 33: 863-870, 2013. doi: 10.1161/ATVBAHA.112.301009.

30) Janssen I, Fortier A, Hudson R, Ross R. Effects of an energy-restrictive diet with or without exercise on abdominal fat, intermuscular fat, and metabolic risk factors in obese women. Diabetes Care 25: 431-438, 2002. doi: 10.2337/diacare.25.3.431.

31) Nicklas BJ, Chmelo E, Delbono O, Carr JJ, Lyles MF, Marsh AP. Effects of resistance training with and without caloric restriction on physical function and mobility in overweight and obese older adults: a randomized controlled trial. Am J Clin Nutr 101: 911-919, 2015.

32) Sipilä S, Suominen H. Effects of strength and endurance training on thigh and leg muscle mass and composition in elderly women. J Appl Physiol 78: 334-340, 1995. 